\title{
Emerging themes in management control: A review of recent literature
}

\author{
A.J. Berry ${ }^{\text {a }}$, A.F. Coad ${ }^{\text {b }}$, E.P. Harris ${ }^{\text {c,* }}$, D.T. Otley ${ }^{\text {d }}$, C. Stringer ${ }^{\mathrm{e}}$ \\ a Manchester Metropolitan University, Manchester, UK \\ ${ }^{\mathrm{b}}$ University of Birmingham, Birmingham, UK \\ ${ }^{\mathrm{c}}$ De Montfort University, Leicester, UK \\ d Lancaster University, Lancaster, UK \\ ${ }^{\mathrm{e}}$ University of Otago, Otago, New Zealand
}

\section{A R T I C L E I N F O}

\section{Article history:}

Received 24 June 2008

Received in revised form

24 September 2008

Accepted 25 September 2008

\section{Keywords:}

Management control

Strategic control

Decision making

Performance management

Organisation

Culture

Control

Risk management

\begin{abstract}
A B S T R A C T
This review starts from the lines of enquiry suggested by Otley et al. [Otley, D.T., Broadbent, J.M., Berry, A.J., 1995. Research in management control: an overview of its development. British Journal of Management 6, S31-S34] and develops these themes in the light of more recently published research. Hence this review is structured around the following emerging themes; Decision making for Strategic Control; Performance Management for Strategic Control; Control Models for Performance Management and Measurement; Management Control and New Forms of Organisation; Control and Risk; Culture and Control; and Practice and Theory.

Whilst research has been evident in all of these areas, relatively little attention has been paid to information and communication technologies and its impact upon control system design and capability, nor did we find much literature on control and gender, or on control and sustainability. Further there has been relatively little research on control and risk or upon control and culture. The limitations of overarching frameworks are noted and we conclude that it seems essential to place more emphasis on research which attends to the relationship of control practices and theory which will require more embedded and collaborative research processes.
\end{abstract}

(c) 2008 Elsevier Ltd. All rights reserved.

\section{Introduction}

This review of the emerging themes in management control builds on earlier reviews, such as Hofstede, 1978; Giglioni and Bedeian, 1974; Merchant and Simons, 1986; Parker, 1986; Macintosh, 1994; and Otley et al., 1995. Giglioni and Bedeian reviewed the contribution of the general management and organisational theory literature for the period 1900-1972. Parker argued that accounting control developments lagged developments in the management literature and criticised accounting models of control for offering only imperfect reflections of management models of control. Hofstede provided an early survey of the behavioural approach to budgetary control, later also noting (1978) "the poverty of (the then) management control philosophy" while Merchant and Simons took a broader view of management control, giving attention to agency theory and psychology. Simons $(1994,1995)$ later contributed to the study of the strategic aspects of control. Macintosh organised his review around the methodological approaches of the researchers. Whilst appreciating the content of the earlier reviews, we will structure this review around the themes developed by Otley et al. (1995).

\footnotetext{
* Corresponding author.

E-mail address: eharris@dmu.ac.uk (E.P. Harris).
} 
Otley et al. (1995) argued that one of the unintended consequences of Anthony's seminal work (Anthony, 1965) was that management control research developed in an accounting-based framework. They noted that radical theorists had given attention to the importance of wider issues of power in a society being expressed or replicated in management control and management controls. Otley et al. also reviewed a series of definitions of management control (Anthony, 1965; Lowe, 1971; Machin, 1983), showing how they were broadening from Anthony's base. Otley et al. (1995) organised their review of management control research using Scott's typology of open and closed systems (Scott, 1981) mapped against rational and natural models of systems. These authors did not claim that such a mapping was complete or the four domains were always mutually exclusive. They noted that while a functionalist stance had been severely criticised (Burrell and Morgan, 1979) it was still a very common approach to management control research and practice. Further they suggested that the advent of powerful computers and high-speed software might have a considerable impact on control practice. Also it was observed that accounting was still an important element of management control, as it offered the possibility of integrating all aspects of an organisation's work into an over-arching economic calculus.

Otley et al. (1995) suggested "some lines of enquiry" that might prove to be fruitful. These were:

(a) The environment of control especially the change in organisational structures from large hierarchies to smaller and more focused units. This introduces a 'horizontal' element into control structures in relation to e.g. supply chains and the embedded firm

(b) The change from a focus on business planning to a wider focus on business strategy and strategic control processes. This includes the appearance of strategic information systems such as the then embryonic balanced scorecard (Kaplan and Norton, 1992)

(c) The impact of globalisation in introducing greater complexity, uncertainty and risk

(d) The methodological basis of management control research; to develop constructivist and critical research studies

(e) Control in multinational organisations in relation to the impact of organisational and national cultures

(f) Ecological sustainability

(g) Control and gender

The production of scholarly reviews, as a valuable addition to the growth of published research, has become more common. The British Academy of Management publishes a journal of these while in a field closely associated with management control there has been the recent publication of two volumes of scholarly reviews of aspects of research on management accounting (Chapman et al., 2007). In these volumes, Chenhall (2007) has reviewed the theorising of contingencies in management control research, eight authors have reviewed research methods, Dechow et al. (2007) have reviewed the relationships between management accounting and information technology in the context of management control of complex organisations, and Langfield-Smith (2007) has considered quantitative research in management control systems. Control and accountability was examined by Merchant and Otley (2007); Abernethy et al. (2007) took a wide ranging look at accounting and control in health care, and Edenburg and Krishnan (2007) reviewed management accounting and control in health care from an economic perspective.

In structuring this review it was tempting to follow the methodological organisation of Macintosh (1994) to examine whether management control literature had developed in different ontological and epistemological ways. It was also tempting to follow the use by Otley et al. of Scott's typology. However, in the light of the previous reviews we chose to take a thematic approach, using the themes which Otley et al. had noted, in order to examine how management control literature had developed in the ensuing decade.

The emerging themes discussed in the following sections include: decision making for strategic control, performance management for strategic control, control models for performance measurement and management, management control and new forms of organisation, control and risk, culture and information technology. This is followed by a discussion of methodological issues in relation to the relationship between practice and theory, discussion, and conclusion.

\section{Decision making for strategic control}

Recent research includes a number of case studies that have examined the making of investment decisions within and across firms in the context of various industry sectors and project types. Haka (2007) lists 6 from 1996 to 2004 (Carr and Tomkins, 1996; Shank, 1996; Miller and O'Leary, 1997; Lee, 2001; Guilding, 2003; O'Connor et al., 2004). Two of these (Lee, 2001 and O'Connor et al., 2004) involved state-owned enterprises in China. Carr and Tomkins (1996) reported an increase in the use of strategic analysis across 51 cases in the motor components industry. Miller and O'Leary (1997) reported a longitudinal case study which examined how the capital budgeting process changed over time, to a more co-ordinated approach with projects grouped into bundles, which may be viewed as a more strategic control.

Langfield-Smith (2005) commented on the limited amount of research on the strategic impact of investment decisions, but highlighted two case-based studies (Miller and O’Leary, 1997; Slagmulder, 1997). Slagmulder (1997) used a grounded theory approach to observe how management control systems changed to adapt to strategic change, by introducing new controls or by changing the degree of formalisation of controls, the tightness of controls, or the locus of decision-making. Also in 1997, 
Smith and Murray (1997) reported the use by managers of a range of coping strategies for dealing with the uncertainties in investment decisions in 6 UK firms.

Harris (1999) identified 7 stages in the Strategic Investment Decision (SID) process in an iterative model, drawn from case analysis, of decisions in a European logistics firm. This study started by examining the type of strategic projects managers regularly had to decide upon and the SID process used to appraise them, before proceeding to identify common sources of risk for each type of project. The focus on business development projects, with some infrastructure (technology development) projects explains why the search for and identification of opportunities tended to start at divisional or business unit level, whereas business acquisition projects would be identified at group board level, so would not be expected to fit this SID process model.

The level of uncertainty was high in these cases, thus they fit the SID criteria set out by Alkaraan and Northcott (2006), the first survey to use the description 'strategic investment decision-making'. They made a distinction between the routine or operational decisions characterised in the 20th century capital budgeting literature, often involving plant and equipment replacement in relatively stable manufacturing environments, and decisions with a more strategic focus in advanced manufacturing technologies. They characterised these more strategic decisions as having high levels of risk, uncertainty and complexity, with significant long term impact on firm performance. Hence risk and uncertainty has become a focus of much SID research.

In earlier literature, heuristics and/or bias in decision making have often been seen as negative, leading to sub-optimal decisions (Eynon, 1988), but more recently have been seen as positive, drawing on emotional intelligence (Gilovich et al., 2002). This is especially relevant when managers form their earliest views on the risks associated with strategic options, for formal or controlled thinking about projects is only feasible later in the SID process when sufficient relevant information has been collected.

Heuristics or 'automatic thinking' occurs more where there are more gaps in the evidence base (Hastie and Dawes, 2001). Using personal construct theory and cognitive maps Harris (2007) explored how managers viewed the risk and uncertainties involved in business acquisitions, thus 'capturing' the risk heuristics applied by board level managers. The cognitive mapping technique was also developed for assessing the uncertainties in innovation projects at the early screening or 'skunkworks' stage, before significant funds were invested (Harris and Woolley, 2009). The action research aimed to increase risk awareness of managers involved in SIDs with high levels of uncertainty, but did not consider risk attitudes. In the projects a framework map was developed for allocating responsibility to individual management team members for investigating specific areas of uncertainty to increase pre-decision or 'task relevant' knowledge.

Risk attitude influences how risk and uncertainty is viewed by managers in relation to SIDs and plays a significant role in decision making (Hillson and Murray-Webster, 2005). Collier et al. (2007, p. 67) adapted Douglas and Wildavsky's model of risk attitudes (Douglas and Wildavsky, 1983) in their study, where respondents' observations were used to map their organisations as fatalists or risk sceptical (7\%), hierarchists (36\%), individualists or entrepreneurs (14\%), or egalitarians or risk aware (43\%). The management accountants surveyed were mostly in the last category as risk aware, where risk management was viewed as both about avoiding negative consequences and achieving positive consequences from decisions made in the organisation. The survey also suggested that risk management was being driven by public calls for improved corporate governance (Collier et al., 2007, p. 71).

The regulation of enterprise risk management (ERM) has been developed through the corporate governance movement, with COSO (2004) setting out a framework for the identification, assessment and reporting of risks that large companies must comply with. However, from a management control perspective the framework has severe limitations, not least ignoring the socio-political dimensions of risk identification and analysis (Williamson, 2007). Woods (2007) explored the overlap between ERM and balanced scorecard (BSC) at Tesco PLC. That paper set out the governance model used internally by the Tesco group and the researcher's interpretation of the communication lines linking risk and strategy (Woods, 2007, p. 1084). We anticipate more studies that focus on how the control processes of ERM are applied in companies.

From the above review of recent SID literature, the emphasis has shifted from management control of capital budgeting to control of strategic investment decision making and control of enterprise risk management.

\section{Performance management for strategic control}

Approaches to studying performance in management control systems (MCS) in organisations included examining objectives, strategy, measures, incentives, and information flows as well as contextual issues, e.g. external environment, organisational culture, social controls and history (Otley, 1999). This integrated approach was necessary to both examine the complex nature of the relationships between strategy and MCS, and to provide some insights into how integrated strategic control systems are used and implemented (Otley, 1999; Ferreira and Otley, 2005). Previous research focused on linkages between strategy and specific elements of MCS. The reviews by Langfield-Smith $(1997,2007)$ concluded that strategic MCS research was fragmentary and findings were often conflicting. Some reasons for this situation included the way MCS had been operationalised from a narrow focus, usually on formal financial controls, with the omission of social control, clan control, culture and context.

There are few examples of authors taking an integrative approach to understanding the MCS strategy linkages. The nature of survey work means that they tended to focus on specific control variables (Chenhall, 2003; Luft and Shields, 2003). Some exceptions included Chenhall and Langfield-Smith (1998) and Baines and Langfield-Smith (2003). Two recent surveys have 
attempted to incorporate informal controls in survey studies. Auzair and Langfield-Smith (2005) included the use of informal communications as part of less bureaucratic controls. Henri (2006b) examined organisational culture (flexibility dominant type versus control dominant type cultures) and found that these cultural-types gave attention to, and used performance measures in different ways.

Field studies, in contrast to surveys, may have been expected to include a wider range of controls. However, a recent review of field studies reported that the literature was partial in terms of the content examined; for example, strategy was mentioned in less than 25\% of the studies (Stringer, 2007). Abernethy and Chua (1996) found that it was necessary to understand the operation of the elements within the overall MCS (or control 'package'), and that the overall mix (design or use) was influenced by the strategic choices of the dominant coalition. A two-way relationship between MCS and strategy was reported in a retrospective longitudinal study as, "the MCS both shapes, and is shaped by, strategy" (Kober et al., 2007, p. 427).

The importance of understanding how formal and informal controls interact in strategic MCS was highlighted in the Astoria case (Frow et al., 2005). Astoria's business unit operations were highly intertwined, and the broader MCS included traditional budgeting procedures, tight financial control, regular feedback, individual accountabilities linked to performance evaluation, and rewards linked to company performance. While managers, individually, were held accountable for items outside of their own control, the resulting control problem was overcome because the formal controls required that managers managed the interdependencies with other areas. While Astoria's managers preferred to influence others informally (through regular meetings and face-to-face contact), the formal procedures assisted in communication and problem solving where issues were not easily resolved. In a different context (an organisation that publicly promoted its commitment to social responsibility), Norris and O'Dwyer (2004) found that informal controls, e.g. social and self controls, dominated the formal control systems that rewarded managers for financial performance (e.g., turnover and profits).

The notion that what gets measured gets attention has long been noted in the literature (Ridgway, 1956). For example, Henri (2006, p. 548) found that performance measurement "used in an interactive (diagnostic) fashion contributed positively (negatively) to the deployment of the capabilities of market orientation, entrepreneurship, innovativeness, and organizational learning." These findings were complementary to other recent studies by Bisbe and Otley (2004) and Abernethy and Brownell (1999).

There has also been increasing debate about which measures should be used. Field studies often highlight the 'noise' in accounting performance measures, and how this can lead to a number of dysfunctional consequences such as gaming and manipulation. Research has examined the use of non-financial measures to improve organisational performance (Ittner et al., 1997; Banker et al., 2000). Other important issues that need to be studied include what performance measures (or combination of measures) are applicable in different organisational settings, and how to weight these measures, especially when they are linked to incentive systems.

While there is (especially in the USA) an extensive literature on executive compensation systems (seeking goal alignment via share options, etc.), little is known about how incentive systems are integrated with the other parts of the performance measurement system, (apart from some anecdotal evidence about (often) unintended consequences). The sensitive nature of incentive systems often means access is difficult, and there is a bias towards 'good news' stories, see Stringer (2006). To understand how incentive systems evolve over time and in-depth, longitudinal studies are needed that analyse the organisational context including the history and background (e.g., prior experiences with incentive systems), and culture. ${ }^{1}$

Further insights have been provided when in-house performance data has been analysed (see Gibbs, 1995; Ittner et al., 2003; Gibbs et al., 2004; Moers, 2005; Matsumura and Shin, 2006). See, for example, the contrasting findings of the benefits (Gibbs et al., 2004) and problems (Ittner et al., 2003) with subjective performance evaluations. An experimental study has reported that providing incentives improved the honesty in reporting (Evans et al. 2001). This contradicted other studies where managers stated that they engaged in a number of dysfunctional activities, e.g. smoothing, advancing or deferring income and expenses (Merchant, 1990). A major issue for experimental studies is the extent to which their findings translated to the real world. Experimental designs usually involved tasks that were short term (one or two hours), were based on simple tasks (compared to the complexity that managers deal with) and provided small incentives compared to the high bonus potentials often available to senior and middle managers.

After several decades of incentive systems we still know little about which design features are more applicable and effective in different situations (Merchant et al., 2003) and there remain a lot of unanswered questions. We do not know what kinds of performance targets are more appropriate in relation to different incentive designs. Few studies have followed Merchant and Manzoni's in-depth analysis of target setting in organisational settings (Merchant and Manzoni, 1989). Organisations typically cap incentive payouts, despite a number of studies showing that this leads to gaming in the target setting process (e.g. Jensen, 2001). Should incentives be formula-based (but open to manipulation), or should subjectivity be allowed to take into account uncontrollable factors (but open to bias)? It appears that a central problem with incentive systems design is the difficulty of anticipating the behavioural responses to the controls.

Recent survey research by Kominis and Emmanuel (2007) linked expectancy theory (intrinsic and extrinsic motivation) with performance measurement systems (e.g. attainability of standards, accuracy of measures, and dependency on rewards).

\footnotetext{
${ }^{1}$ One of the authors conducted a study in a UK bank. Most people received above average ratings, but believed they received below average ratings. Why did this occur? The reason appears to have been that the 'grapevine' is notoriously unreliable. In their after work conversations people would tend to say they got more than they really did. The result was that most people were dissatisfied with their bonus payments, a waste of $10 \%$ of the bank's salary bill.
} 
Surveying middle managers in the same organisation was important, because the diversity in incentive system designs across organisations makes it difficult to interpret cross-sectional data.

While strategy, performance measurement, and incentive systems are key components in understanding the operation and performance management and control systems, it is also important to understand the integrative nature of these key components that leads to the discussion in the next section.

\section{Control models for performance measurement and management}

Three models of integrated performance measurement systems have emerged in the literature: strategic performance measurement systems (SPMS) like Kaplan and Norton's balanced scorecard; Simons' levers of control; and Ferreira and Otley's performance management and control framework.

\subsection{SPMS}

SPMS have become popular ways of linking organisational objectives and strategy to performance measurement systems. Kaplan and Norton's balanced scorecard (BSC) (Kaplan and Norton, 1996, 2001, 2004, 2006, 2008) is one example. Their integrative nature is a feature of these SPMS as they link strategy to performance measures and to other systems including operations, human resources e.g., performance evaluations, information technology, as well as to customer and supplier networks and the value chain (Chenhall, 2005).

Recent studies have highlighted issues in terms of the use and implementation of BSC. Once again studies have shown that it was important to understand the formal and informal control systems. For example, Ittner et al. (2003) found that the BSC was used differently than intended by the designers; allowing superiors to have discretion in the choice of measures and weightings used in performance evaluations resulted in high levels of subjectivity, some measures of future performance were ignored, financial measures were emphasised, evaluation criteria were changed and measures were emphasised that did not support desired results. This introduced subjectivity that resulted in favouritism and uncertainty in the reward system, so that the system was subsequently abandoned.

Malina and Selto (2001) found causal relationships between effective management control, motivation, strategic alignment and beneficial effects of the BSC, but also found a number of problems arising, including inaccurate and subjective measures, top-down directed communication, lack of participation and inappropriate benchmarks being used for evaluation. A problem with most approaches to SPMS was that they took a top-down management approach to control and were focused on designing control tools and techniques (e.g., strategy maps, business unit scorecards, personal scorecards). The variety in the design and use of BSC meant that it was often unclear what organisations were using when they said that they have adopted a balanced scorecard (Ax and Bjørnenak, 2005). The lack of attention to informal controls and organisational context may have been one reason why BSC implementation has been so difficult and why these techniques are adapted to specific circumstances in organisations.

\subsection{Levers of control}

Simons (1995) contributed to a broadening of the role of MCS. His argument focused around balancing four levers of control: interactive, diagnostic, belief and boundary systems. Simons provided a more complex conceptualisation "to the use of MCS to manage behaviour and effect strategic change" (Langfield-Smith, 2007, p. 778). Survey research has tended to focus on Simon's interactive and diagnostic levers and the use of specific controls including budgets (Abernethy and Brownell, 1999), performance measures (Henri, 2006a); and the interactive use of broader MCS (e.g., budgets, BSC) in product development (Bisbe and Otley, 2004).

From longitudinal case studies Bruining et al. (2004) concluded that belief and interactive control systems serve as a valuable complement and extension to, but not replacement of, the more traditional diagnostic control systems. In an entrepreneurial organisation, Collier (2005) found that informal controls such as group norms, socialisation, and culture were more important than formal controls. He also observed how modes of control evolve over time. Linking SPMS and Simons' levers, Tuomela, (2005) found that a new SPMS was used interactively and diagnostically; but belief systems (e.g., customer focus reinforced through the customer satisfaction perspective) and boundary systems (e.g., focus on key customers) were also important. He observed that there were only minimal changes to the reward systems possibly because the development of the SPMS was at the middle management level (rather than top-down). Context was also important as there was resistance to change as new information made actions more visible, power structures shifted and workloads increased.

The way the administrative controls were used, through observing an empowered approach compared to a more restricted approach, influenced the impact on strategy (Marginson, 2002). He also found that there were biases in performance measurement (i.e., financials were important), different measures received attention at different times but the measures were used diagnostically and interactively by top managers.

While Simons' "levers of control" do attempt to include informal controls, his conceptualisation of belief systems did not include other important informal controls such as group norms, socialisation and culture (Collier, 2005). Another limitation was that Simons' levers were developed at the senior management level (Simons, 1994), and so may only apply to that level. 


\subsection{Performance management and control framework}

A model, which builds on Simons' levers of control approach, was inductively developed by Otley (1999) and Ferreira and Otley (2005) from their case study research at the middle management level. ${ }^{2}$ Ferreira and Otley (2005) provided a 12- question framework to assist researchers who wished to examine an 'integrated' performance and management control framework (PMC). The questions were broad enough to cover the entire PMC process, focused on the interconnections between the various parts of the framework and provided a systematic way to categorise and discuss case findings.

The development of the PMC framework is in its early stages, and is open to extension. The PMC has featured in recent empirical studies (Ferreira, 2002; Ferreira and Otley, 2005; Collier, 2005), Otley (1999) and was used by Stringer (2006) and Tuomela, (2005) to structure their case findings. An earlier version (Otley, 1987) was used by Otley (1992) and by Moon and Fitzgerald (1996). The organisational culture part of the PMC was extended by Broadbent and Laughlin (2007).

One criticism of the PMC was there was little advice on the interconnections between the questions (Malmi and Granlund, 2005). Another issue raised was the need to understand the antecedents, background and organisational context of a performance management system design. The concern was that a PMC could still be focused on the formal system design, rather than the system in use (Collier, 2005). Collier (2005) also argued that the PMC did not incorporate the benefit of Simon's (2005) belief and boundary systems. Most of these criticisms can be overcome by using an in-depth and longitudinal field study approach, so that a range of performance management issues are able to emerge.

\section{Management control and new forms of organisation}

This section of the paper considers new organisational forms and empirical evidence of the consequences of new organisational forms for the design of management control systems.

\subsection{New organisational forms}

The concept of 'new organisational forms' has gained currency during the last two decades. It appears to be shorthand for a wide range of phenomena involving organisational restructuring of both internal and external boundaries (Van der MeerKooistra and Scapens, 2004). The new organisational forms literature asserts there has been a move from the bureaucratic hierarchical form, considered ineffective in the context of increased competition brought about by globalisation, deregulation, the emergence of powerful developing economies and developments in information technologies, towards flatter, leaner and thus more responsive structures. A variety of methods have been deployed to bring about this increased flexibility. They included downsizing, delayering, the use of autonomous and cross-functional work teams, the centralisation of core activities and shared services, a growth in subcontracting and outsourcing and the creation of strategic alliances, networks and supply chains. In popular management discourse, the emerging forms have been characterised as 'virtual', 'boundaryless', 'flat', 'lean' and 'intelligent' organisations (Ezzamel et al., 2005).

Despite some ostentatious claims of widespread organisational transformation, especially in the 'guru' literature, e.g. Drucker (1992) and Handy (1995), academic research has questioned the extent of change, suggesting transformation is more prevalent in some sectors, such as internet retailing, high technology industries, and the public sector; elsewhere it has been more incremental in nature, motivated as much by cost cutting as visions of becoming more flexible or focusing on core competences (Ezzamel et al., 2005; Smith et al., 2005). This research has concluded that where organisational transformation exists, it may well presage a wider diffusion of new organisational forms; nevertheless, such organisational forms may simply arise from and within a very specific business environment.

At a conceptual level, the notion of new organisational forms is not entirely uncontroversial. Hodgson (2002), for example, argues there is no good reason to abandon the formal, legal conception of the firm even in the light of the seeming blurring of organisational boundaries. Whereas others argue that the co-ordination and control required through task forces, crossfunctional teams and inter-organisational networks demands hybrid relational arrangements that are quite distinct from the traditional dichotomy of markets and hierarchies forms (Berry, 1994; Zenger, 2002; Van der Meer-Kooistra and Scapens, 2004). One solution to reconcile these perspectives is to keep the traditional organisation-market distinction on legal grounds, but to supplement it with a more refined understanding of control and co-ordination mechanisms used within the two governance structures (Foss, 2002). For example, it may make sense to think of internal hybrids as representing the infusion of hierarchies with elements characteristic of the market, such as TQM, autonomous work teams and group based incentives (Zenger, 2002). Similarly, external hybrids may be controlled in part by both formal arrangements such as project teams, inter-organisational budgets and performance management systems, and informal characteristics, such as the development of trusting relationships that are traditionally found in hierarchies e.g. Dekker (2004).

\footnotetext{
${ }^{2}$ Otley (1999) was inductively developed and was intended to include a case study where it was applied, but reference to this had to be dropped when permission to use the field data was refused. Ferreira and Otley (2005) was based on four case studies in Portuguese companies.
} 


\subsection{Internal hybrids}

The term 'horizontal organisation' has been used to highlight a perspective which views organisations as structured around a small number of business processes, or work flows, which link the activities of an organisation to the needs and capabilities of suppliers and customers (Ostroff and Smith, 1992). It is a perspective that has led to calls for management control researchers to pay more attention to lateral relationships, which involve co-operation and coordination amongst managers at similar levels of the hierarchy (Otley, 1994; Hopwood, 1996; Van der Meer-Kooistra and Scapens, 2004). Whilst modern organisations tend to be flatter, they are still hierarchies. So the challenge for management control is to develop concepts and systems that orchestrate both horizontal and vertical relationships.

Techniques such as activity-based cost management (Kaplan and Cooper, 1998) and the balanced scorecard (Kaplan and Norton, 1996, 2001) can provide ways of thinking about cost, value and performance that connect parts of the value chain between suppliers and customers. But they are not without their critics, given that major expectations of horizontal organisation are to encourage flexibility and learning, both of which often require effective co-ordination across the internal (functional) boundaries of organisations. Activity-based cost management, once established in an organisation, has been criticised for introducing rigidity into cost and organisational structures, whereas the cause-and-effect relationships at the heart of balanced scorecard modelling have been challenged on the basis of empirical justification (Nørreklit, 2000; Chenhall, 2008).

Perhaps more promising research into the relationship between management control and horizontal organisation has focused on the concept of responsibility accounting, which for several decades has linked organisation theory and management control theory. As originally conceived, it presented a model of organisations divided into responsibility centres, such as departments or divisions, where managers were individually accountable for sub-unit performance. Central to responsibility accounting has been the controllability principle: the notion that a manager should be evaluated only on that which he or she controls (Antle and Demski, 1988). However, recent research focussing on internal boundary spanning activities problematises notions of individual controllability on which responsibility accounting is traditionally based (Van der Meer-Kooistra and Scapens, 2004; Frow et al., 2005; Rowe et al., 2008). For example, Rowe et al. (2008) redefine responsibility accounting more broadly, so as to include interdependent or joint activities in which groups of responsibility centre managers, perhaps operating in committees or multi-functional teams, are jointly accountable for their aggregate performance:

Thus, instead of focusing on RA (responsibility accounting) principally as a mechanism for managing individual RC (responsibility centre) managers vertically up and down an organizational hierarchy..., we focus on RA as a mechanism for horizontally managing groups, teams, or committees of several functionally differentiated RC managers who work on a common organizational value chain or organizational process (Rowe et al., 2008).

Similarly, Dent (1987) described the control processes in an organisation producing computing systems. Superficially, management control was along traditional lines, with market forecasts supporting the production of annual budgets, manufacturing divisions accountable as cost centres, and both systems development divisions and distribution divisions accountable as profit centres. However, formal planning was not a continuous activity in the company, despite the rapid rate of change in the company's product-markets. Whilst planning created a sense of corporate direction, strategic renewal and operational coordination was achieved through a complex pattern of spontaneous interaction between divisional managers. The structure of the control system was significant in encouraging this interaction. The accounting system was designed in such a way that costs of manufacturing divisions were traced to the profit centres and revenues were simultaneously credited both to the relevant development and distribution divisions. Consequently, the usual controllability principle was violated because responsibility exceeded authority and managers depended on others to achieve their own unit's performance targets. This created tensions in the organisation, encouraging unit managers to think beyond their functional tasks and to negotiate with managers of other units to act on their behalf.

Taken together, the studies by Frow et al. (2005), Rowe et al. (2008) and Dent (1987) provide some preliminary evidence suggesting how management control theory must develop to reconcile the needs for predictability, central control and synergies on the one hand and more informal horizontal relationships encouraging strategic renewal and change on the other. We must question traditional approaches to responsibility accounting, with their emphasis on individual level accountabilities and the controllability principle:

...contrary to the received wisdom, evidence emerged...to suggest that managers actually found their lack of controllability positively 'challenging'. Managers imbued with expectations that interdependencies were integral to company activities and that managers should take responsibility for managing them, drew upon relevant management control procedures, and combined these with informal social interaction, to resolve tensions arising at the interface between accountability and (a lack of) controllability (Frow et al., 2005, p. 289).

The emerging (case study) evidence suggests that whilst strategic renewal often resulted from informal communication processes, such socialising forms of control were reinforced and facilitated by formal control procedures. This insight has led to suggestions that 'minimal structures' are required in organisations to provide rules and procedures to regulate horizontal relationships, but simultaneously leaving room for manoeuvre to enable the parties to act flexibly, share information, and create opportunities for learning (Van der Meer-Kooistra and Scapens, 2004). 


\subsection{External hybrids}

In addition to increased fluidity of internal boundaries within organisations, the past two decades have witnessed a tremendous rise in hybrid organisational forms (Van der Meer-Kooistra and Vosselman, 2006). Correspondingly, recognition that management control is no longer confined to the legal boundaries of organisations (Otley, 1994), and following calls for more explicit attention to be paid to the management control of supply chains and networks of organisations (Berry, 1995; Hopwood, 1996; Seal et al., 1999), there has been a proliferation of papers examining the issue of control between organisations. To date, the literature has primarily focused on dyadic relationships, reflecting evidence that whilst practicing managers tend to have some understanding of how the entire supply network works, it tends to be managed link by link, with little or no systemic analysis (Berry et al., 2000). More recently, there has been some change in the level of analysis, with empirical studies recognising dyadic relationships as but one element in a wider network of interconnections (e.g. Håkansson and Lind, 2004; Lind and Thrane, 2005; Mouritsen and Thrane, 2006).

Some of the most far-reaching changes in form, structure and control of organisations in a number of countries have been observed in public sectors. Whilst there has been some variation between countries, from the 1980s onwards new public management reforms have sought to introduce into public sector organisations managerial processes from the private sector. Such reforms have become increasingly influential determinants of organisational forms, with agencies becoming divisionalised, management becoming 'corporate', and services being provided on the basis of real or quasi-contracting out. A relatively recent extension of these reforms has been the introduction of Public Private Partnerships (PPPs), in which private sector organisations supply services, that also require the financing, design and building of infrastructure, to a public sector purchaser for a period of 30- 60 years, in return for annual payments, which are effectively lease charges (Broadbent and Laughlin, 2005). Recent research in the UK indicated 43\% of National Health Service Trusts and one-third of local authorities have entered into some form of strategic alliance or partnership (Ezzamel et al., 2005). With these developments, the image of central and local governments as unitary, hierarchical organisations has become increasingly unsustainable.

The use of accounting technologies has been central to the development of new public management reforms. They include new financial reporting systems, the introduction of devolved budgets, changes to both internal and external public audits, the development of performance measurement systems and the use of key performance indicators (Moll and Humphrey, 2007). These developments have been accompanied by a proliferation of public sector management literature, which has served to highlight the controversies and tensions evident in new public management reform:

These include the degree to which the reforms are: enabling or controlling; devolving or centralising; under- or overauditing; delivering on their promises or dominated by unintended consequences; and/or aided by a privileged status through which implementation problems are assumed as teething troubles, rather than being acknowledged as fundamental problem of design (Moll and Humphrey, 2007. p. 299).

The aim of PPPs is to overcome some of the problems previously evident in public sector infrastructure projects where new assets were delivered late and often over budget. The expectation was that increasing competition in the tendering process and sharing the risks between public and private sectors would lead to long-term value for money and gains from innovation (Froud, 2003), but recent research has called into question the achievement of these aims. For example, in a briefing report (ACCA, 2002) a number of PPPs were identified where the degree of risk transfer was open to debate, while Froud and Shaoul (2001) highlighted significant problems in the appraisal and evaluation of PPPs. Elsewhere, there have been calls for clearer definitions of the terms value for money and risk, together with more proactive post-project evaluation, highlighting quantification of costs and transferred risks over the entire life of the project (Broadbent et al., 2004). Whilst these debates will continue, it is clear that PPP projects are here to stay, and they represent significant challenges for management control.

In the private sector, the developing research literature of hybrid organisational forms may be classified in terms of its underlying theories (e.g. Van der Meer-Kooistra and Vosselman, 2006; Håkansson and Lind, 2007; Kraus and Lind, 2007). Much of the early work was primarily influenced by transaction cost economics. Particularly influential was Williamson $(1985,1996)$, who argued that three distinct modes of governance could be identified at a generic level: markets, hierarchies and hybrids. These modes differ in the control mechanisms they employ to safeguard contract execution and to achieve successful adaptation: market governance derives control from competition between organisations; hierarchical governance achieves control by means of devices such as authority, incentives and monitoring; whereas hybrid governance encompasses a wide variety of inter-organisational relationships, including joint ventures, buyer-supplier relationships, franchising and licensing agreements (Speklé, 2001; Dekker, 2004).

The transaction cost economics perspective suggests that the sources of an organisation's success may lie in arranging the architecture of the entire value system in such a way that it is part of an efficient transaction cost minimising structure. In such a manner, collaborating networks of organisations may be more efficient than either a single organisation spanning the network or many separate organisations competing in a market. Advantages of market transactions, such as efficiency incentives, are preserved, whilst the benefits of hierarchy, such as knowledge sharing and reduced need for contractual controls, are also achieved. Ultimately, however, the distinction between market and hierarchy becomes an artificial one, because the vast majority of organisations use a wide range of contractual and institutional arrangements.

Whilst it offers an explanation of the existence of hybrid organisational forms at a generic level, transaction cost economics does have a number of limitations. In particular, it provides very limited insights into the processes that lead to the adoption, use and evolution of governance and control systems in hybrid relationships (Van der Meer-Kooistra and Vosselman, 2006). 
As such, it does not take into account the potential for control structures and practices to facilitate or hinder information flows or to shape and re-shape the relationships between collaborating parties, thereby creating new boundaries or blurring existing ones.

In response, Dekker (2004) added insights from both management control theory and organisation theory, arguing that inter-organisational relationships require both formal and informal control mechanisms. Formal control consists of contractual obligations, service level agreements, structural arrangements, planning procedures, performance monitoring and reward systems. Informal control, also referred to as social control and relational governance, includes informal cultures and systems influencing members, and essentially relates to mechanisms encouraging self-regulation. In respect of informal controls, a number of studies have particularly focused on the notion of trust between collaborating parties. Trust has been defined in a variety of ways, but frequently refers to an expectation, based on experience, that a partner will not behave in an opportunistic manner (Tomkins, 2001). In hybrid relationships, high levels of trust are expected to reduce costs of governance (e.g. coordination and monitoring costs, enforcement arrangements), increase relationship investments in specific assets, encourage wider inter-organisational activities, and increase the performance of partner organisations (Van der Meer-Kooistra and Vosselman, 2000; Dekker, 2003; Langfield-Smith and Smith, 2003). But research evidence suggests that the relationship between trust and control is rather complex. At least four approaches are evident: trust has been examined as an alternative to control (Dekker, 2003); the existence of effective control systems can help build trust (Seal et al., 1999); control structures and practices may themselves be objects of trust (Busco et al., 2006a; Mouritsen and Thrane, 2006); and trust may be a necessary condition for the adoption of some control practices, such as open-book accounting (Cooper and Slagmulder, 2004).

Other researchers have drawn on actor network theories to examine ways in which inter-organisational relationships are constructed and governed. Here, a distinction is made between 'actors' (humans) and 'actants' (non-humans), but it is assumed that both are equally capable of acting (Latour, 1987; Law, 1991, 1992). In this perspective, accounting and control systems can be conceptualised as actants, helping to build, shape and mediate inter-organisational relationships through both self regulation and orchestration (Mouritsen and Thrane, 2006). The self-regulating mechanisms unobtrusively facilitate interaction and exchange, while orchestration mechanisms involve structuring these interactions. Elsewhere, Håkansson and Lind (2004) demonstrated how management control systems with overlapping accountabilities in inter-organisational environments created contradictions which required actors continuously to find provisional solutions to problems. In this manner, management control was implicated in orchestrating a dynamic inter-organisational network that could develop and change despite the embeddedness of actors, activities and resources and the complexities of interdependence.

\subsection{Change in systems of management control}

Over the years, the concept of change in management control systems has been studied from functionalist, behavioural, interpretive and critical perspectives. But recent studies have been particularly influenced by institutional theories and actornetwork theories, both of which will be briefly reviewed in this sub-section.

Studies in the tradition of New Institutional Sociology (NIS) assume that organisations compete not only for resources and customers but also for political power and institutional legitimacy. From this perspective, the logics of change in management control systems are diffused throughout organisations by means of three processes: coercive, mimetic and normative (DiMaggio and Powell, 1983). As such, control technologies are adopted not so much as a result of a rational choice process, but rather to meet organisational needs for social and political legitimacy (Brignall and Modell, 2000; Collier, 2001; Modell, 2001).

However, this perspective has been criticised for depicting the processes of change as being linear and inescapable, where actors become voluntarily isomorphic to institutions or that the institutions mould them involuntarily, with little resistance to change (Quattrone and Hopper, 2001; Dambrin et al., 2007).Thus, early work in the tradition of NIS gave insights into how inter-organisational change diffuses, but few insights into the processes of intra-organisational change. It was partly to counter these criticisms that Burns and Scapens (2000) developed a framework which combined themes from structuration theory, Old Institutional Economics and the work of Barley and Tolbert (1997) to provide an evolutionary perspective on the ways rules and routines structure organisational activity over time. Their framework stimulated research into how management control systems develop over time, why there might be resistance to such changes, the interplay between management accountants and other agents of change, revolutionary versus evolutionary changes, relationships between trust and control, and the loose coupling of rules and routines (e.g. Soin et al., 2002; Granlund and Modell, 2005; Busco et al., 2006b; Lukka, 2007).

Moreover, recent work in the tradition of NIS has examined similar intra-organisational phenomena, demonstrating the processes of institutionalisation to be neither as systematic nor as linear as the early studies had suggested. It has shown how the need for external legitimisation often conflicts with the requirements of internal management control systems. As a consequence, institutionally induced control practices are often decoupled from the control systems actually used to control operations, and we have begun to recognise more clearly the role of coalitions of interest and the importance of power in change processes (Burns, 2000; Dillard et al., 2004; Granlund and Modell, 2005; Dambrin et al., 2007).

Themes of power and interest are also evident in studies of change that draw upon insights from actor-network theories. From this perspective, management control innovations such as ABC or BSC diffuse through organisations because of their ability to serve the transitory interests of various groups of actors who are looking to maintain or improve their position and influence (Chua, 1995). As a consequence, the adoption of an innovation's technical characteristics is an insufficient criterion 
to judge the 'success' or 'failure' of its diffusion; especially as notions of success and failure are problematic within this epistemological stance. Instead, actor-network theory focuses attention on the dynamics of unforeseeable interactions within and between actor-networks, such as the arguments used (or not) by members of a network to promote or reject an innovation in control systems, so as to maintain their position of influence and successfully enrol the interests of others (Chua, 1995; Mouritsen, 1999).

Actor-network theory has contributed to our understanding of change in management control systems through highlighting how technologies such as ABC or BSC may be used to stabilise and mediate diverse interests, are adopted for multiple reasons, may be made to work temporarily and then abandoned, act as a basis for mobilising networks, reconstituting organisational knowledge and standardising skills at a distance (Briers and Chua, 2001; Jones and Dugdale, 2002; Ezzamel et al., 2004; Alcouffe et al., 2008). It has also called into question conventional notions of time and space in management control systems and draws the attention of researchers towards constantly changing loci of control and a-centred organisations (Lowe, 2004; Quattrone and Hopper, 2005).

\subsection{MC and new forms of organisation: Conclusions and implications for future research}

Research progress is being made in respect of management control and new forms of organisation. We have identified the key challenge for management control in internal hybrids is to develop concepts and systems that orchestrate both horizontal and vertical relationships. Some promising developments have indicated the need for a redefinition of the concept of responsibility accounting, so as to focus on how to manage groups of functionally differentiated managers working on common organisational processes or projects (Rowe et al., 2008). Others have observed deliberate violation of the controllability principle to create tensions which encourage unit managers to engage in informal social interaction beyond their functional boundaries (Dent, 1987; Frow et al., 2005). But much more case research is necessary to yield insights into how organisations can develop effective rules and procedures to regulate horizontal relationships, whilst simultaneously encouraging managers to act flexibly, share information, and create opportunities for learning.

In respect of external hybrids, we have seen how accounting technologies have been central to the development of new public management reforms, and a diverse body of literature has served to highlight the controversies and tensions evident in such reforms. In the private sector, research has been directed towards understanding the development of hybrid governance structures (Speklé, 2001), the co-ordination of interdependent tasks and the management of appropriation concerns (Dekker, 2004). Both formal and informal mechanisms have been observed, with special attention being focused on the implications of trust for the management control of inter-organisational relationships. More recently, actor network theories have drawn our attention to issues which mirror tensions evident in the domain of internal hybrids; where management control systems help build, shape and mediate inter-organisational relationships, creating contradictions which require managers continuously to find provisional solutions to problems through informal social interaction, self-regulation and orchestration (Håkansson and Lind, 2004; Mouritsen and Thrane, 2006).

However, much remains to be done to improve our understanding of control in both internal and external hybrid organisational arrangements. The emphasis on the concept of trust in several existing studies has served to highlight the collaborative nature of hybrid arrangements. Far less attention has been devoted to understanding the implications of power and politics in the development and control of hybrid arrangements. Collaboration beyond internal and external boundaries often involves co-ordination between groups with divergent and sometimes mutually inconsistent goals and interests. How these groups form and interact, and the implication of these processes for the design of control systems, are interesting avenues for exploration. Additionally, only scant attention has been paid to how powerful external groups and institutions might also influence the design of hybrid control structures.

Another dimension that warrants further research is the interaction between the internal control systems of companies, and those used for inter-organisational control. Whilst studying inter-organisational cost management, Coad and Cullen (2006) used evolutionary theory to explore how organisational actors employ search routines, leading to unpredictable modifications to activities, costs and organisational boundaries. Their analysis indicated that the learning and change evident in these modifications is facilitated by previously instituted capabilities that appear to spill over from the organisational domain to the inter-organisational domain and vice versa. By implication, similar processes might be at work in the development, use and modification of inter-organisational control; indicating an area for potentially fruitful research.

More generally, the evaluation of the performance of hybrid organisational arrangements has received very limited research attention. Earlier, we noted calls that have been made for more active post-project evaluation of Public Private Partnerships, including the quantification of costs and the transfer of risks over the entire life of projects (Broadbent et al., 2004). Similar calls could be made for more general evaluation of horizontal organisational and inter-organisational initiatives. The post-implementation evaluation of such things as outsourcing arrangement, strategic alliances, the development of internal service centres, and the use of multi-functional project teams requires much more investigation.

Finally, there appears to be a gap between the theory and practice of management control for new organisational forms. There is very limited evidence of active involvement by management accountants, in the processes of design, operation, adaptation and abandonment of new organisational forms. This may reflect prejudice against management accountants on the part of more powerful organisational interest groups (e.g. human resources, information systems, marketing, strategic management). Or it may be symptomatic of a lack of understanding of hybrid organisational arrangements and their control by management accounting practitioners (Chenhall, 2007). Whatever the reason, this gap warrants further research. 


\section{Other emerging themes}

\subsection{Control and risk}

Control has been viewed as a process of rational choice but the long history of the interaction of human and organisational behaviour and control has been marked (Otley et al., 1995). Human reasoning and decision making is more dependent on schema-based inference processes informed by the individual's content-specific knowledge and personal experiences (Anderson, 2000, pp. 350-351). In relation to risk and uncertainty human reasoning differs from normative probability based theories (Kahneman and Tversky, 1979, prospect theory). Otley and Berry (1980) used statistics to explore how uncertainty and risk affected, and were accommodated in, budgeting and budget setting processes. Many later studies have found that managers rarely use statistical models or assessments of probability. Berry and Collier (2007) found little or no evidence of use of statistics in risk aspects of Management Control. These authors also noted that the assumption that an organisation could have a control of risk might lead to such an organisation facing a further risk of control if it acted as though all the risks it faced were always captured in the control processes. There are an increasing number of relevant phenomena identified by cognitive psychologists that may be termed 'heuristics' or bias in decision making (Gilovich et al., 2002). These include the emotional responses to experiences of control, the 'affect' heuristic (Fineman and Sturdy, 1999). "Success in the real world depends much more on deploying content-specific knowledge than on being able to correctly apply modus tollens", (Anderson, 2000, p. 351).

\subsection{Control and culture}

In addition to the issues in social theory noted above, three basic propositions about culture and control may be suggested;

(i) Culture is dominated by control; in this sense managers can choose (design) organisational culture (Peters and Waterman, 1982; Schein, 1985; Simons, 1995).

(ii) Culture is control; for it establishes norms, cognitions, etc., which shape everything and control also reconstitutes culture (Homans, 1950).

(iii) Culture dominates control; norms, cognitions and modes of order shape control structures and procedures, (Scott, 1995). Studies following Hofstede (2001) show differences in control practices in different countries. While Hofstede's research methodology, data and findings have been hotly contested especially from constructivist standpoints. Ouchi's consideration of clan control in organisations to both complement and influence markets and hierarchic controls led him to the view that clan control was more likely where outputs were not easily measurable and where transformation processes were ill understood (Ouchi, 1980).

Earlier studies of culture and control were based upon field studies (Birnberg and Snodgrass, 1988; Dent, 1991) which explored the interplay of culture and control processes. In this tradition Ahrens and Mollona (2007) conceived organisational control as cultural practice. There have been few studies of culture and control. Interestingly the two volumes of reviews on management accounting (Chapman et al., 2007) did not provide a review of management accounting and culture, but did include a section in Volume II on management accounting around the world covering four Latin countries of Europe, China, Britain, German speaking countries, the USA, Nordic countries of Europe, and Japan. The two country comparative study of control by Quattrone and Hopper (2005) is a rare contribution to this area of control research. It seems that this line of enquiry suggested by Otley et al. (1995) has much scope for future research.

\subsection{Control and information technology}

During the past two decades the rate of development of information technologies (IT) to support organisational processes has increased dramatically. Technologies such as enterprise resource planning systems (ERP), inter-organisational information sharing mechanisms, internet, intranet and database technologies, suggest new possibilities for modelling organisational operations, integrating organisational activities and managing the firm in real time. Yet the relationships between management control and new IT remain underdeveloped both theoretically and practically. Some studies have suggested that the adoption of ERP systems has had little impact on management control because the new technologies were perceived as cumbersome, accounting technologies were often transferred from the old system to the new one, both firms and consultants had limited knowledge of the potential of the new technologies, and the new systems failed to support some management accounting innovations such as ABC and horizontal information systems (Granlund and Malmi, 2002).

In contrast, another strand of literature is beginning to emerge which seeks to understand how new IT is implicated in the 'system' of control as practised in the context of organisational conditions and concerns. These studies illustrate how organisational actors address the deficiencies of new technologies, such as ERP systems, and find alternative ways to effect organisational integration through the adoption of local systems and practices which complement the organisation-wide technologies (Quattrone and Hopper, 2001, 2005; Chapman, 2005; Dechow and Mouritsen, 2005). The effects of such practices often include the 'hybridisation' of the accounting function, where management accountants experience 
a broadening of their responsibilities and legitimised competencies, whilst simultaneously, non-accountants assume scorekeeping, attention-directing and problem solving responsibilities, formerly considered the domain of the accounting department (Burns and Baldvinsdottir, 1999; Caglio, 2003; Scapens and Jazayeri, 2003). Such studies show the relationship between management control and IT to be a complex one, which also warrants further research.

\section{Control: Practice and theory}

Much of the foregoing review has touched in one way or another on the complex relationship between theory and practice. In this section it will be argued that control research needs to build a new knowledge production process to enable better and more fruitful links between practice and theory.

\subsection{Gaps?}

This 'gap' or relationship between theory and practice has been framed in three ways:

- as a knowledge transfer problem;

- as representing distinct kinds of knowledge; and

- $\quad$ as a knowledge production problem (Van de Ven and Johnson, 2006).

The transfer of knowledge is usually conceived as flowing from academic knowledge producers to practitioners, but it may be a reverse process and may be richer if the processes were interactive. The knowledge transfer between the practice of accounting and economic theory was addressed by Scapens:

We believed that once practitioners were aware of the new models they would apply them in practice. The problem was they never really did (Scapens, 2006, p. 3) and Research to describe practice was urgently needed. (Scapens, 2006, p. 4).

As Hopwood (2007, p. 1368) stated:

Global knowledges are often not very tolerant of local ones and yet sometimes they experience difficulty embedding themselves into the detail of local institutional contexts: the new knowledges remaining only loosely coupled to the settings in which they operate and thereby unable to infuse the functioning of practice.

Of course it may be that practice (as complex behaviours) and theory (as discourse specific, abstract and partial relationships) are such different kinds of knowledge that they can not be interactively related. This gap was illustrated by two managers: ${ }^{3}$

"there is always somebody with some new ideas or principles to apply to our world, but they never understand how complicated our world is, or how limited their ideas are."

"theory and theorists claim power over practice by claiming to understand and explain it, without quite knowing how partial their understanding and explanations were."

Further, academics have been interested in how practitioners speak: "Many of the conversations contained poetic languagestories, metaphors, images and phrases that stuck in my mind and gave me a vivid sense of the managers' experience" (Cunliffe, 2002, p. 136) for we in our day- to- day work use constructs from multiple stances, state relationships, impute causality and so on but not in very precise terms. In this sense Shotter (1993) claimed that managers are also authors, not as writers of texts but as "practical ethical authors" and as "conversational authors" arguing for the next "landscape" of possibilities.

However, it is possible to argue that rules and routines are institutionally (socially constructed) determined and are the context within which practices exist. So these rules or routines (or modes of regulation) constitute control. What interested Bourdieu (1977) was how a rule or routine came into being and was maintained without it ever being written down or formally promulgated. Ahrens and Chapman (2007, p. 16), picked up this thread when they noted that "organisational members reconstituted the practice of management control as skilful practical activity".

It will be suggested here that control research could also be addressed as a knowledge production problem.

\subsection{Socio-technical artefacts for control}

Management control is socially enacted with artefacts and these are both technical and social. Rarely do organisations make their own artefacts, but they do modify the ones they have inherited or had installed. Few control academics (exceptions were Simons, 1995 and Otley, 1999) were in the business of making artefacts (this was left to that interesting community, the consultants, including Kaplan and Norton).

\footnotetext{
${ }^{3}$ In conversation with one of the authors (A.J.B.).
} 
Table 1

Control artefacts.

\begin{tabular}{llll}
\hline Complexity & Artefacts & Technical control artefacts & Socio-technical control artefacts \\
\hline Simple & Hammer & A budget & Budgeting process \\
Middle range & Numerical control machines & ABC & Cost management structures and processes \\
& Auto-pilots & Linear programme models & \\
Complex & Stealth bombers & Financial reports & Financial control structures and processes \\
& Power stations & Balanced scorecards & Global financial control structures and \\
Highly complex & Systems of machines & Computer-based supply chain & processes using systems (SAP; Oracle) \\
& Power networks & models & \\
\hline
\end{tabular}

It is conjectured that these socio-technical artefacts (Table 1) are embodiments of both practice and theory (and culture); in that they are rich deposits from the struggles to create them and their modification through experience of using them. As noted earlier, Simons' work is important here because it focused our attention on how management control systems are used, rather than whether the systems are used, and as a result, evidence is beginning to emerge on the benefits of interactive use of control systems (Abernethy and Brownell, 1999; Vaivio, 2004).

\subsection{Towards new knowledge production in control research}

The construction of new (better?) socio-technical control artefacts is posed as a challenge of knowledge production which may be best accomplished by engagement into the space between practice and theory (Berry, 2006).

Here Shotter (2003) makes some suggestions as to how may this be done. Considering knowledge in relation to the philosophy of Wittgenstein; "His investigations are thus, not at all aimed at developing explanatory theories, but at working from within our already existing practices - like action researchers - to seek previously unnoticed openings for their further refinement, elaboration and correction" (Shotter, 2003, p. 298).

What is needed in these investigations is not to explain from existing theories but to work with "people's spontaneous, embodied expressive-reactions to events occurring" to produce "detailed descriptive studies of the unfolding dynamics of our practices and the part played in them-and in their reflective development-by talk and texts" in order to avoid the privileging of theory and method, (Shotter, 2003). And further, conversations can be central to these enquiries (Cunliffe, 2001, 2002). Hopwood (2007) makes similar points about accounting:

Accounting, as a practice, can be and indeed should be constantly examined, re-examined, interrogated, and criticized within the world of knowledge and other ways need to be found to disturb the status quo. Could this emerge, one wonders, if there were more links to the community of practice so that accounting could be seen in its full diversity and complexity? (Hopwood, 2007, p. 1370)

So to ensure that the 'gaps' or relationship between theory and practice are held in creative tension there is a need to develop theory and practice as a collaborative activity following the modes of action research (Lewin, 1946; Tavistock Institute; Reason and Rowan, 1981; Reason, 1994). In this sense perhaps control academics should more actively engage with practitioners in the manner of consultants, ${ }^{4}$ not surrender their independence of thought and build upon Argyris' notion (Argyris, 1952) of an action science to explicitly organise action research and consultancy activities. (Eijnatten and Dikstra, 2005).

This means a complementary approach to studying control to create abstract ideas that may be generalisable by also studying the socio-technical artefacts and practices that enable or disable control, and the practices of managerial control.

Three features of a new regime for knowledge production would be to enable:

- $\quad$ strong links between researchers and managers at all levels;

- collaboration across research projects; and

- the creation of a sustained collaborative infrastructure for research (Fraser et al, 2002).

The task here is not to explain the practice of others but to collaborate in knowledge building. Three lines of development are suggested based upon:

- the sense making agendas of Weick (1995);

- the approach of Bourdieu (1997) in relation to a theory of practice; and

- the human, social and institutional knowledge agenda set out by Thorpe et al. (2005) and Berry (2006).

This approach to developing knowledge in control systems may be uncomfortable for those who stress the importance of academic knowledge in leading practice, where practice is seen as the application of academic knowledge. It may be equally

\footnotetext{
${ }^{4}$ Academics and consultants seem to find difficulties in working together. However, the potential benefits are such that this difficulty might repay examination.
} 
uncomfortable for those practitioners who see academic knowledge as merely describing and explaining practice, with little further engagement expected. It may however bring a quiet smile to those who design and develop control artefacts for they work in a world where solutions are crafted from available theory, practice and experience. What is sought in our approach is a virtuous cycle where the interdependence of abstract knowledge and the rigorous construction of artefacts depend critically upon mutual engagement.

\section{Discussion}

The management control themes examined in this review have been; decision making and performance management for strategic control, control models for performance measurement and management, management control and new forms of organisation, other emerging themes (e.g. risk, culture), and control practice and theory. The theoretical roots of this management control research are multiple, but with most studies still in the functionalist and positivist traditions, especially applicable to the strategic and performance issues where economics and accounting are central. Economic and social theories become linked in studies of inter-organisational control.

\subsection{Control: Competition and collaboration}

Control between and within organisations has been viewed in the context of principal-agent relationships (the principal seeking alignment of agent behaviour with her goals) with special attention to issues of asymmetric information, power and alignment of agents' behaviour, with control viewed as conflictual and arrangements becoming contractual, however imperfect. Many organisations with high levels of dependency on innovation and performance have discovered that collaborative rather than conflictual relationships give better results (Seal et al., 2004; Berry, 2005). The pursuit of interorganisational (and intra-organisational) arrangements for minimising transaction costs was based upon consideration of three ideal types of relationship: market (control via competition); hybrid (control via partnerships alliances and networks) and hierarchy (control via power and authority) (Williamson, 1973). In any inter-organisational field these three ideal types of control may be present simultaneously (Berry, 2005).

Other theoretical perspectives not included here include moral philosophy and ethics (McPhail et al., 2005; Rosanas and Velilla, 2005), ecology, sustainability and the impact of finite resources (Ball and Milne, 2005), and gender.

\subsection{Suggestions for further research}

There is still a general coherence around the central theme of management control, namely the achievement of overall organisational goals and objectives through the (sometime loosely) coordinated actions of individuals and groups within organisations. This approach has yielded a wide variety of interesting and useful insights into MCS operation, but at the cost of appearing disorganised and sometimes incoherent itself. As the preceding review indicates, the field of MCS research is fragmented, with different researchers examining different aspects of control systems design and use, often adopting very different theoretical perspectives.

Clearly, in such a situation it makes little sense to attempt to impose a research agenda. Rather we attempt to suggest some pathways forward that will enable MCS research to continue to develop in the future. It might well be argued that it is the diversity of approaches that have existed in the field that have generated many of the most fruitful insights, so uniformity is not necessarily a good way forward, even if it were to be possible. However, there do appear to be some common challenges that have made the study of MCS so rewarding, and there may be an advantage in reviewing these for future researchers to keep in mind.

There appear to be three main features of control systems that have strongly influenced the way in which the field has developed. First, it is recognised that MC is a reciprocal activity, where one group of people attempt to impose controls on inherently self-controlling sub-groups. This leads both to so-called dysfunctional reactions, where the sub-groups react so powerfully to a control system that its intention is totally subverted, and to a fundamental uncertainty in being able to predict the outcome of a control action in such circumstances. Static analysis is therefore of very limited use given the dynamic nature of control systems design, use and effects.

Second, MCSs are socially constructed artefacts (people design them) that create a very real social context for those upon whom they are imposed that can fundamentally affect behaviours. It is this interplay between rational design and socially constructed realities that makes the study of control systems so challenging and interesting.

Third, a wide range of contextual factors condition the consequences of control activities. This had led to the development of contingency theories that attempt to allow for these contextual effects. However, context has so many relevant dimensions that often work in opposing directions that the establishment of an integrated contingency theory seems all but impossible. Further, contingencies may vary from situation to situation and develop dynamically over time in such a way as to make their deterministic specification infeasible.

This has two major implications. First, the development of over-arching frameworks, whilst useful, is unlikely to yield a satisfactory theoretical framework. The framework developed by Anthony (1965) has guided much MCS research, but it has more recently become apparent that it has also limited research by its underlying model of hierarchical organisations and accounting-based control systems. More recent frameworks, such as those proposed by Simons (1995), Otley (1999) 
and Ferreira and Otley (2005), have a role in locating studies in a wider field, but are also themselves inherently limited. The framework suggested by Herath (2007) links four control themes from Otley (1996) (as a set of rules, practices, procedures and feedback, as the management of contextual factor dependency, as a set of behavioural mechanisms and as a set of dynamic cultural values) with organisational structure, strategy, culture and information systems to achieve objectives.

Second, it seems essential that more emphasis should be placed on the study of real control systems as they operate in practice. Theoretical speculation has its place, but it needs to be strongly grounded in organisational reality. This is especially true of an integrative activity such as MCS design and use. The advantages of field studies in this context are considerable. They help ensure that the many factors that influence the results of a control systems operation are considered. They help focus on issues that are very real to organisations, and they allow the changes that occur over time to be monitored.

The factors that are required to conduct successful field studies of control systems include:

- A considerable investment in time to enable the observation of multiple aspects of MCS operation and their mutation over time.

- The use of research teams to enable an organisational presence at important times, and to allow different perspectives to be brought to bear on the interpretation of data.

- The development of sound relationships with organisational managers to allow such studies to be conducted, and to provide benefits for such sponsors without compromising academic integrity.

The development of such studies (which have been conducted on a small scale in the past, (e.g. the NCB study, Berry et al., 1985) will require some investment and collaboration, but could also result in a rich set of outcomes that will allow for the development of more integrated theories in this important field.

\section{Conclusions}

Management Control continues to be a fertile field of research development, and this review has followed the lines of enquiry suggested by Otley et al. (1995). While research has been evident in all of these themes there has been relatively little attention paid to information and communication technologies and their impact upon control system design and capability which is a concern given the rapid advances in technical capability in these areas. Further, there has been relatively little research on control and risk or upon control and culture. The limitations of overarching frameworks were noted and it seems essential to place more emphasis on research which attends more specifically to the relationship of control practice and theory, which will require more embedded and collaborative research processes. Research from this perspective is seen neither as academic-led (with academic knowledge being transferred to practice) nor as practice-led (with the academic contribution being relegated to the description and perhaps explanation of practice). Rather it should be framed as a collaborative exercise actively involving both sets of participants.

Such an approach would also help prevent the imposition of pre-determined and partial theories to explain practice. By grounding research in organisational practices, it becomes legitimate to use a wide range of theoretical approaches in helping explain such activities. In addition, research also becomes enmeshed in the design process for management control systems, which exposes it to the crucial trade-offs that have to be considered at every stage. Finally, it opens the door to more dynamic, action research type activities which attempt to observe the consequences of management control systems design and use over a period of time following a change. This is likely both to enrich theory and to assist practice.

Management control continues to be a major concern for organisations of all types. Changes in individual expectations, the social and economic environment, and in technological capability have transformed control practices over the 40 or so years since Anthony developed his framework. Yet much of the fundamental analysis performed over these years remains valid. The challenge is to separate the fundamental and unchanging principles from the contingent practices that develop in specific contexts and environments. We hope that this review will help researchers to be aware of what has been done in the past, so as to move on from a firmer foundation: to neither re-invent the wheel nor remain tied to it!

\section{Acknowledgements}

All the authors are members of the Management Control Association (MCA), a small charitable foundation which runs quarterly research workshops and a triennial international conference. They are grateful to participants for their comments on an earlier version of this paper presented at the MCA conference held at ESCP-EAP in Paris, in September 2007.

\section{References}

Abernethy, M.A., Brownell, P., 1999. The role of budgets in organizations facing strategic change: an exploratory study. Accounting, Organizations and Society 24, 189-204.

Abernethy, M.A., Chua, W.F., 1996. A field study of control system “redesign": The impact of institutional Processes on Strategic Choice. Contemporary Accounting Research $13(2), 569-606$.

Abernethy, M.A., Chua, Y.F., Grafton, J., Mahama, H., 2007. Accounting and control in health care: behavioural, organisational, sociological and critical perspectives. In: Chapman, C.S., Hopwood, A., Shields, M.D. (Eds.), Handbook of Management Accounting Research. Elsevier, Oxford, pp. 805-830. 
ACCA, 2002. The Private Finance Initiative: A Briefing. ACCA, London.

Ahrens, T., Chapman, C.S., 2007. Management Accounting as Practice. Accounting Organizations and Society 32 (1-2), 1-27.

Ahrens, T., Mollona, M., 2007. Organisational control as cultural practice-A shop floor ethnography of a Sheffield steel mill. Accounting Organisations and Society $32(4-5), 305-331$.

Alkaraan, F., Northcott, D., 2006. Strategic capital investment decision-making: a role for emergent analysis tools? A study of practice in large UK manufacturing companies. British Accounting Review 38 (2), 149-173.

Alcouffe, S., Berland, N., Levant, Y., 2008. Actor-networks and the diffusion of management accounting innovations: a comparative study. Management Accounting Research 19, 1-17.

Anderson, J.R., 2000. Cognitive Psychology and its Implications. Worth, New York.

Anthony, R.N., 1965. Planning and Control Systems: A Framework for Analysis. Graduate School of Business Administration, Harvard University, Boston, MA.

Antle, R., Demski, J.S., 1988. The controllability principle in responsibility accounting. The Accounting Review 63, 700-718.

Argyris, C., 1952. The Impact of Budgets on People. Controllership Foundation Inc., U.S.

Auzair, S.M., Langfield-Smith, K., 2005. The effect of service process type, business strategy and life cycle stage on bureaucratic MCS in service organisations. Management Accounting Research, 399-421.

Ax, C., Bjørnenak, T., 2005. Bundling and diffusion of management accounting innovations-the case of the balanced scorecard in Sweden. Management Accounting Research, 1-20.

Baines, A., Langfield-Smith, K., 2003. Antecedents to management accounting change: a structural equation approach. Accounting, Organizations and Society $28,675-698$

Ball, A., Milne, M.J., 2005. Sustainability and management control. In: Berry, A.J., Broadbent, J., Otley, D.T. (Eds.), Management Control: Theories, Issues and Performance, second ed. Palgrave Macmillan, Basingstoke, pp. 314-337.

Banker, R.D., Potter, G., Srinivasan, D., 2000. An empirical investigation of an incentive plan that includes nonfinancial performance measures. The Accounting Review 75 (1), 65-92.

Barley, S.R., Tolbert, P.S., 1997. Institutionalization and structuration: studying the links between action and institution. Organization Studies 18 , 93-117.

Berry, A.J., 1994. Spanning traditional boundaries: organization and control of embedded operations. Leadership and Organization Development Journal 15 (7), 4-10

Berry, A.J., 1995. Control in networks. Paper presented at the Third International Conference on Management Control Systems Research, London.

Berry, A.J., 2005. Control in Networks. In: Berry, A.J., Broadbent, J.M., Otley, D.T. (Eds.), Management Control, Theories, Issues and Practices. Macmillan, Basingstoke.

Berry, A.J., 2006. The space between theory and practice. MCA Workshop, Paris. May 2006.

Berry, A.J., Collier, P.M., 2007. Risk in supply chains: exploratory case studies in the automotive industry. International Journal of Risk Assessment and Management 7 (8), 1005-1026.

Berry, A.J., Capps, T., Cooper, D.T., Ferguson, P., Hopper, T., Lowe, T., 1985. Management Control in an area of the NCB: Rationales of accounting practices in a public enterprise. Accounting, Organizations and Society 10 (1), 3-28.

Berry, A.J., Ahmed, M., Cullen, J., Dunlop, A., Seal, W., 2000. The Consequences of Inter-firm Supply Chains for Management Accounting. CIMA, London.

Birnberg, J., Snodgrass, C., 1988. Culture and control: a field study. Accounting, Organizations and Society 13 (5), 447-464.

Bisbe, J., Otley, D., 2004. The effects of the interactive use of management control systems on product innovation. Accounting, Organizations and Society 29 (8), 709-737.

Bourdieu, P., 1977. Outline of a Theory of Practice. Cambridge University Press.

Briers, M., Chua, W.F., 2001. The role of actor-networks and boundary objects in management accounting change: a field study of an implementation of activity-based costing. Accounting, Organizations and Society 26, 237-269.

Brignall, S., Modell, S., 2000. An institutional perspective on performance measurement and management in the "new public sector". Management Accounting Research 11, 281-306.

Broadbent, J., Laughlin, R., 2005. The role of PFI in the UK Government's modernisation agenda. Financial Accountability and Management 21, 75-97.

Broadbent, J., Laughlin, R., 8-10 July 2007. Performance Management Systems: A conceptual Model and analysis of the development and intensification of 'New public Management' in the UK. Paper presented at the APIRA Conference, Auckland.

Broadbent, J., Gill, J., Laughlin, R., 2004. Evaluating the Private Finance Initiative in the National Health Service: Nature, Emergence and the Role of Management Accounting in Decision Making and Post-decision Project Evaluation. CIMA, London.

Bruining, H., Bonnet, M., Wright, M., 2004. Management control systems and strategy change in buyouts, 155-177.

Burns, 2000. The dynamics of accounting change: interplay between new practices, routines, institutions, power and politics. Accounting, Auditing and Accountability Journal 13, 566-596.

Burns, J., Baldvinsdottir, G., 1999. Hybrid accountants: where do they belong and what (are they expected) to do? Paper presented at the Conference on Management Accounting Change-a European Perspective, Manchester, April 1999.

Burns, J., Scapens, R.W., 2000. Conceptualizing management accounting change: an institutional framework. Management Accounting Research 11, 3-25.

Burrell, G., Morgan, G., 1979. Sociological Analysis and Organisational Analysis. Heinemann, London.

Busco, C., Frigo, M., Giovannoni, E., Riccaboni, A., Scapens, R.W., 2006a. The Role of Performance Measurement Systems within Global Organizations. ICAEW, London.

Busco, C., Riccaboni, A., Scapens, R.W., 2006b. Trust for accounting and accounting for trust. Management Accounting Research 17, 11-41.

Caglio, A., 2003. Enterprise resource planning systems and accountants: towards hybridization? European Accounting Review 12, 123-153.

Carr, C., Tomkins, C., 1996. Strategic investment decisions: the importance of SCM. A comparative analysis of 51 case studies in U.K., U.S., German companies. Management Accounting Research 7, 199-217.

Chapman, C., 2005. Not because they are new: developing the contribution of enterprise resource planning systems to management control research. Accounting, Organizations and Society 30, 685-689.

Chapman, C.S., Hopwood, A.G., Shields, M.D., 2007. Handbook of Management Accounting Research. Elsevier, Oxford.

Chenhall, R.H., 2003. Management control systems design within its organizational context: findings from contingency-based research and directions for the future. Accounting, Organizations and Society 28, 127-168.

Chenhall, R., 2005. Integrative strategic performance measurement systems, strategic alignment of manufacturing, learning and strategic outcomes: an exploratory study. Accounting, Organizations and Society 30 (5), 395-422.

Chenhall, R.H., 2007. Theorising contingencies in management control research. In: Chapman, C.S., Hopwood, A., Shields, M.D. (Eds.), Handbook of Management Accounting Research. Elsevier, Oxford, pp. 163-206.

Chenhall, R.H., 2008. Accounting for the horizontal organization: a review essay. Accounting, Organizations and Society 33 (4-5), 517-550.

Chenhall, R., Langfield-Smith, K., 1998. The relationship between strategic priorities, management techniques and management accounting: an empirical investigation using a systems approach. Accounting, Organizations and Society 23 (3), 243-264.

Chua, W.F., 1995. Experts, networks and inscriptions in the fabrication of accounting images: a story of the representation of three public hospitals. Accounting, Organizations and Society 20, 111-145.

Coad, A.F., Cullen, J., 2006. Inter-organisational cost management: towards an evolutionary perspective. Management Accounting Research 17, 342-369.

Collier, P.M., 2001. The power of accounting: a field study of local financial management in a police force. Management Accounting Research 12, 465-486.

Collier, P., 2005. Entrepreneurial control and the construction of a relevant accounting. Management Accounting Research 16, 321-339. 
Collier, P., Berry, A.J., Burke, G.T., 2007. Risk and Management Accounting: Best Practice Guidelines for Enterprise-Wide Internal Control Procedures. Elsevier, Oxford.

Cooper, R., Slagmulder, R., 2004. Interorganizational cost management and relational context. Accounting. Organizations and Society 29, 1-26.

COSO, 2004. Enterprise Risk Management-an integrated framework. Committee of Sponsoring Organisations of the Treadway Commission.

Cunliffe, A., 2001. Managers as practical authors: reconstructing our understanding of management practice. Journal of Management Studies 38 (3), 351-357.

Cunliffe, A., 2002. Social poetics as management inquiry: a dialogical approach. Journal of Management Inquiry 11 (2), 128-146.

Dambrin, C., Lambert, C., Sponem, S., 2007. Control and change: analysing the process of institutionalisation. Management Accounting Research 18, $172-208$.

Dechow, N., Mouritsen, J., 2005. Enterprise resource planning systems, management control and the quest for integration. Accounting, Organizations and Society 30, 691-733.

Dechow, N., Granlund, M., Mouritsen, J., 2007. Management control of complex organisation; relationship between management accounting and information technology. In: Chapman, C.S., Hopwood, A., Shields, M.D. (Eds.), Handbook of Management Accounting Research. Elsevier, Oxford, pp. 625-640.

Dent, J.F., 1987. Tension in the design of formal control systems: a field study in a computer company. In: Bruns, W.J., Kaplan, R.S. (Eds.), Accounting and Management-Field Study Perspectives. Harvard Business School Press, Boston, pp. 119-145.

Dent, J.F., 1991. Accounting and organisational cultures: A field study of the emergence of a new organizational reality. Accounting, Organizations and Society $16(8), 705-732$.

Dekker, H.C., 2003. Value chain analysis in interfirm relationships: a field study. Management Accounting Research 14, 1-23.

Dekker, H.C., 2004. Control of inter-organizational relationships: evidence on appropriation concerns and coordination requirements. Accounting, Organizations and Society $29,27-49$.

Dillard, J.F., Rigsby, J.T., Goodman, C., 2004. The making and remaking of organization context: duality and the institutionalization process. Accounting, Auditing and Accountability Journal 17, 506-542.

DiMaggio, P.J., Powell, W.W., 1983. The iron cage revisited: institutional isomorphism and collective rationality in organizational fields. American Sociological Review 48, 147-160.

Douglas, M., Wildavsky, A., 1983. An Essay on the Selection of Technological and Environmental Dangers. University of California Press, Los Angeles.

Drucker, P., Sept-Oct 1992. The new society of organizations. Harvard Business Review, 95-104.

Edenburg, L., Krishnan, R., 2007. Management accounting and control in health care: an economics approach. In: Chapman, C.S., Hopwood, A., Shields, M.D. (Eds.), Handbook of Management Accounting Research. Elsevier, Oxford, pp. 859-884.

Eijnatten, F., Dikstra, L., 2005. Improvement and transfer of practice-directed knowledge. Quality and Quantity 3 (2), 137-154.

Evans, J.H., Hannan, R.L., Krishnan, R., Moser, D.V., 2001. Honesty in managerial reporting. The Accounting Review 76 (4), 537-559.

Eynon, P.J., Nov-Dec 1988. Avoid the Seven Deadly Sins of Strategic Risk Analysis. The Journal of Business Strategy 9 (6), 18-22.

Ezzamel, M., Lilley, S., Wilmott, H., 2004. Accounting representation and the road to commercial salvation. Accounting, Organizations and Society 29 , $783-813$.

Ezzamel, M., Morris, J., Smith, J.A., 2005. Accounting for New Organisational Forms: The Case of Subcontracting and Outsourcing. CIMA, London.

Ferreira, A.M.F., 2002. Management Accounting and Control System Design and Use: An Exploratory Study in Portugal. PhD thesis, Lancaster University.

Ferreira, A., Otley, D., 2005. The Design and Use of Management Control Systems: An Extended Framework for Analysis. Social Science Research Network. http://papers.ssrn.com/sol3/papers.cfm?abstract_id=682984.

Fineman, S., Sturdy, A., 1999. The emotions of control: a qualitative exploration of environmental regulation. Human Relations 52 (5), $631-663$.

Foss, N.J., 2002. Introduction: new organizational forms-critical perspectives. International Journal of the Economics of Business 9, 1-8.

Fraser, I., Lanier, D., Hellinger, F., Eisenberg, J.M., 2002. Health Services Review 37.1, xiii-xxvi.

Froud, J., 2003. The private finance initiative: risk, uncertainty and the state. Accounting, Organizations and Society 28, 567-589.

Froud, J., Shaoul, J., 2001. Appraising and evaluating PFI for NHS hospitals. Financial Accountability and Management 17, 247-270

Frow, N., Marginson, D., Ogden, S., 2005. Encouraging strategic behaviour while maintaining management control: multi-functional project teams, budgets, and the negotiation of shared accountabilities in contemporary enterprises. Management Accounting Research 16, 269-292.

Gibbs, M., 1995. Incentive compensation in a corporate hierarchy. Journal of Accounting and Economics 19, 247-277.

Gibbs, M., Merchant, K.A., Stede, Van der, Wim, A., Vargus, M.E., 2004. Determinants and Effects of Subjectivity in Incentives. The Accounting Review 79 (2), 409-436.

Giglioni, G.B., Bedeian, A.B., 1974. A conspectus of management control theory; 1900-1972. Academy of Management Journal, 292-305.

Gilovich, T., Griffin, D., Kahneman, D. (Eds.), 2002. Heuristics and Biases: The Psychology of Intuitive Judgement. Cambridge University Press, New York.

Granlund, M., Malmi, T., 2002. Moderate impact of ERPS on management accounting: a lag or permanent outcome? Management Accounting Research 13, 299-321.

Granlund, M., Modell, S., 2005. Nordic contributions to management accounting change literature. In: Jönsson, S., Mouritsen, J. (Eds.), Accounting in Scandinavia-The Northern Lights. Liber and Copenhagen Business School Press, Malmo, pp. 159-192.

Guilding, C., 2003. Hotel owner/operator structures: implications for capital budgeting process. Management Accounting Research 14 (2), 179-199.

Haka, S., 2007. A Review of the literature on capital budgeting and investment appraisal: past, present, and future musings. In: Chapman, C.S., Hopwood, A.G., Shields, M.D. (Eds.), Handbook of Management Accounting Research, Vol. 2. Elsevier, Oxford, pp. 697-728.

Håkansson, H., Lind, J., 2004. Accounting and network coordination. Accounting, Organizations and Society 29, 51-72.

Håkansson, H., Lind, J., 2007. Accounting in an interorganizational setting. In: Chapman, C.S., Hopwood, A.G., Shields, M.D. (Eds.), Handbook of Management Accounting Research, Vol. 2. Elsevier, Oxford, pp. 885-902.

Handy, C., 1995. The Empty Raincoat: Making Sense of the Future. Arrow Business, London.

Harris, E., 1999. Project risk assessment: a European field study. British Accounting Review 31 (3), 347-371.

Harris, E.P., 2007. How managers construe risk in business acquisitions. International Journal of Risk Assessment and Management 7 (8), $1057-1073$.

Harris, E., Woolley, R., 2009. Facilitating Innovation through Cognitive Mapping of Uncertainty. International Studies of Management and Organization 39 (1).

Hastie, R., Dawes, R., 2001. Rational Choice in an Uncertain World. Sage, Thousand Oaks, CA.

Herath, S.K., 2007. A framework for management control research. Journal of Management Development 26 (9), 895-915.

Henri, J.-F., 2006a. Management control systems and strategy: a resource-based view. Accounting, Organizations and Society 31, 529-558.

Henri, J.-F., 2006b. Organizational culture and performance measurement systems. Accounting, Organizations and Society 31 (1), 77-103.

Hillson, D., Murray-Webster, R., 2005. Understanding and Managing Risk Attitude. Gower, Aldershot.

Hofstede, G., July 1978. The poverty of management control philosophy. Academy of Management Review.

Hofstede, G., 2001. Culture's Consequences: Comparing Values, Behaviors, Institutions, and Organizations Across Nations, second ed. Sage Publications,

Thousand Oaks, CA.

Hodgson, G.M., 2002. The legal nature of the firm and the myth of the firm-market hybrid. International Journal of the Economics of Business 9, 37-60.

Homans, G., 1950. The Human Group. Harcourt and Brace, New York.

Hopwood, A.G., 1996. Looking across rather than up and down: on the need to explore the lateral processing of information. Accounting, Organizations and Society $21,589-590$.

Hopwood, A.G., 2007. Whither accounting research? The Accounting Review 82 (5), 1365-1373.

Ittner, C.D., Larcker, D.F., Rajan, M.V., 1997. The choice of performance measures in annual bonus contracts. The Accounting Review 72 (2), $231-255$.

Ittner, C.D., Larcker, D.F., Meyer, M.W., 2003. Subjectivity and the weighting of performance measures: Evidence from a balanced scorecard. The Accounting Review 78 (3), 725-759.

Jensen, M., 2001. Corporate budgeting is broken-let's fix it. Harvard Business Review 70 (10), 95-101. 
Jones, T.C., Dugdale, D., 2002. The ABC bandwagon and the juggernaut of modernity. Accounting, Organizations and Society $27,121-163$.

Kahneman, D., Tversky, A., 1979. Prospect theory: an analysis of decision under risk. Econometrica 47 (2), $263-291$.

Kaplan, R.S., Cooper, R., 1998. Cost and Effect: Using Integrated Cost Systems to Drive Profitability and Performance. Harvard University Press, Boston, MA.

Kaplan, R.S., Norton, D.P., Jan/Feb 1992. The balanced scorecard- measures that drive performance. Harvard Business Review, 71-79.

Kaplan, R.S., Norton, D.P., 1996. Translating Strategy into Action. The Balanced Scorecard. Harvard Business School Press, Boston, MA

Kaplan, R.S., Norton, D.P., 2001. The Strategy Focused Organization: How Balanced Scorecard Companies Thrive in the New Business Environment. Harvard Business School Press, Boston, MA.

Kaplan, R.S., Norton, D.P., 2004. Strategy Maps: Converting Intangible Assets into Tangible Outcomes. Harvard Business School Press, Boston, MA.

Kaplan, R.S., Norton, D.P., 2006. Alignment. Using the Balanced Scorecard to Create Corporate Synergies. Harvard Business School Press, Boston, MA.

Kaplan, R.S., Norton, D.P., 2008. Mastering the Management System. Harvard Business Review 86 (1), $63-77$.

Kober, R., Ng, J., Paul, B.J., 2007. The interrelationship between management control mechanisms and strategy. Management Accounting Research 18 (4), 425-452.

Kominis, G., Emmanuel, C.R., 2007. The expectancy-valence theory revisited: Developing an extended model of managerial motivation. Management Accounting Research 18 (1), 49-75.

Kraus, K., Lind, J., 2007. Management control in inter-organisational relationships. In: Hopper, T., Northcott, D., Scapens, R. (Eds.), Issues in Management Accounting. FT Prentice Hall, Harlow, pp. 269-296.

Langfield-Smith, K., 1997. Management control systems and strategy: a critical review. Accounting, Organizations and Society 22 (2), $207-232$.

Langfield-Smith, K., 2005. What Do We Know about Management Control Systems and Strategy? In: Chapman, C.S. (Ed.), Controlling Strategy. Oxford University Press, New York, pp. 62-85.

Langfield-Smith, K., 2007. A review of quantitative research in management control systems and strategy. In: Chapman, C.S., Hopwood, A., Shields, M.D. (Eds.), Handbook of Management Accounting Research. Elsevier, Oxford, pp. 753-784.

Langfield-Smith, K., Smith, D., 2003. Management control systems and trust in outsourcing relationships. Management Accounting Research 14, 281-307.

Latour, B., 1987. Science in Action: How to Follow Scientists and Engineers Through Society. Harvard University Press, Cambridge, MA.

Law, J. (Ed.), 1991. A Sociology of Monsters. Essays on Power, Technology and Domination. Routledge, London.

Law, J., 1992. Notes on the theory of actor-network: ordering, strategy and heterogeneity. Systems Practice 5, 379-393.

Lee, C., 2001. Financial restructuring of state owned enterprises in China: the case of Shanghai Sunve Pharmaceutical Corporation. Accounting, Organizations and Society 26, 673-689.

Lewin, K., 1946. Action research and minority problems. Journal of Social Issues 2, 34-60.

Lind, J., Thrane, S., 2005. Network accounting. In: Jönsson, S., Mouritsen, J. (Eds.), Accounting in Scandinavia-The Northern Lights. Liber and Copenhagen Business School Press, Malmö, pp. 115-137.

Lowe, E.A., 1971. On the idea of a management control system; Integrating accounting and management control. Journal of Management Studies, $213-227$.

Lowe, A., 2004. Post-social relations: towards a performative view of accounting knowledge. Accounting, Auditing and Accountability Journal 17, 604-628.

Luft, J., Shields, M.D., 2003. Mapping management accounting: graphics and guidelines for theory-consistent empirical research. Accounting, Organizations and Society 28, 169-249.

Lukka, K., 2007. Management accounting change and stability: loosely coupled rules and routines in action. Management Accounting Research 18, 76-101.

Machin, J., 1983. Management control systems; whence and whither? In: Lowe, E.A., Machin, J. (Eds.), New Perspectives in Management Control. Macmillan, Basingstoke, pp. 22-42.

Macintosh, N.B., 1994. Management Accounting and Control Systems; An Organisational and Behavioural Approach. Wiley, Chichester.

Malina, M.A., Selto, F.H., 2001. Communicating and controlling strategy; an empirical study of the effectiveness of the balanced scorecard. Journal of Management Accounting Research 13, 47-90.

Malmi, T., Granlund, M., 2005. In: Search of Management Accounting Theory, Social Science Research Network. http://papers.ssrn.com/sol3/papers. cfm?abstract_id=804004.

Marginson, D.E.W., 2002. Management control systems and their effects on strategy formation at middle-management levels: Evidence from a U.K. organisation. Strategic Management Journal 23 (11), 1019.

Matsumura, E.A., Shin, Jae Yong, 2006. An empirical analysis of an incentive plan with relative performance measures: evidence from a postal service. The Accounting Review 81 (3), 533-566.

McPhail, K., Gorringe, T., Gray, R., 2005. Crossing the great divide; critiquing the sacred secular dichotomy in accounting research. Accounting, Auditing and Accountability Journal 18 (2), 185-188.

Merchant, K.A., 1990. The effects of financial controls on data manipulation and management myopia. Accounting, Organizations and Society 15 (4), 297-313.

Merchant, K.A., Manzoni, J., 1989. The achievability of budget targets in profit centres: a field study. The Accounting Review LXIV (3), 539-558.

Merchant, K.A., Otley, D.T., 2007. A review of the literature on control and accountability. In: Chapman, C.S., Hopwood, A., Shields, M.D. (Eds.), Handbook of Management Accounting Research. Elsevier, Oxford, pp. 785-803.

Merchant, K.A., Simons, R., 1986. Research and control in complex organisations-an overview. Journal of Accounting Literature, 181-203.

Merchant, K.A., Van der Stede, W., Zheng, L., 2003. Disciplinary constraints on the advancement of knowledge: the case of organizational incentive systems. Accounting, Organizations and Society 28, 251-286.

Miller, P., O'Leary, T., 1997. Capital Budgeting Practices and Complementarity Relations in the Transition to Modern Manufacture: a field-based analysis. Journal of Accounting Research 35, 257-271.

Modell, S., 2001. Performance measurement and institutional processes: a study of managerial responses to public sector reform. Management Accounting Research 12, 437-464.

Moers, F., 2005. Discretion and bias in performance evaluation: the impact of diversity and subjectivity. Accounting, Organizations and Society $30,67-80$.

Moll, J., Humphrey, C., 2007. Management accounting and accountants in the public sector: the challenges presented by public-private partnerships. In: Hopper, T., Northcott, D., Scapens, R. (Eds.), Issues in Management Accounting. FT Prentice Hall, Harlow, pp. $297-315$.

Moon, P., Fitzgerald, L., 1996. Delivering the goods at TNT: the role of the performance measurement system. Management Accounting Research 7, 431-457.

Mouritsen, J., 1999. The flexible firm: strategies for a sub-contractor's management control. Accounting, Organizations and Society $24,31-55$.

Mouritsen, J., Thrane, S., 2006. Accounting, network complementarities and the development of inter-organizational relations. Accounting, Organizations and Society 31, 241-275.

Nørreklit, H., 2000. The balance on the balanced scorecard: a critical analysis of some of its assumptions. Management Accounting Research 11, 65-88.

Norris, G., O'Dwyer, B., 2004. Motivating socially responsive decision making: the operation of management controls in a socially responsive organisation. British Accounting Review 36 (2), 173-196.

O'Connor, N., Chow, C., Wu, A., 2004. The adoption of “Western" management accounting/controls in China's state-owned enterprises during economic transition. Accounting, Organizations and Society 29, 349-375.

Ostroff, F., Smith, D., 1992. The horizontal organization. McKinsey Quarterly 1, 148-167.

Otley, D., 1987. Accounting Control and Organizational Behaviour. Heinemann Professional Publishing Ltd, Oxford.

Otley, D., 1992. United Bank: a case study on the implementation of a performance-related reward scheme. In: Bruns Jr., W.J. (Ed.), Performance Measurement, Evaluation and Incentives. Harvard Business School Press, Boston, MA, pp. 97-121. Chapter 4.

Otley, D.T., 1994. Management control in contemporary organizations: towards a wider framework. Management Accounting Research 5, $289-299$.

Otley, D.T., 1996. Some issues in Management control. In: Vagneur, K., Wilkinson, C., Berry, A.J. (Eds.), Beyond Constraint; Exploring the Management Control Paradigm. The Management Control Association, London. 
Otley, D., 1999. Performance management: a framework for management control systems research. Management Accounting Research 10, 363-382.

Otley, D.T., Berry, A.J., 1980. Control, organisation and accounting. Accounting, Organizations and Society 5 (2), 231-246.

Otley, D.T., Broadbent, J.M., Berry, A.J., 1995. Research in management control: an overview of its development. British Journal of Management 6, S31-S34.

Ouchi, W.G., 1980. Markets, Bureaucracies and Clans. Administrative Science Quarterly 25 (1), 129-141.

Parker, L.D., 1986. Developing Control Concepts in the 20th Century. Garland, United States.

Peters, T.J., Waterman, R.H., 1982. In Search of Excellence. Harper and Rowe, New York.

Quattrone, P., Hopper, T., 2001. What does organizational change mean? Speculations on a taken for granted category. Management Accounting Research $12,403-435$.

Quattrone, P., Hopper, T., 2005. A “time-space odyssey": management control systems in two multinational organizations. Accounting, Organizations and Society 30 (7-8), 735-764.

Reason, P., 1994. Participation in Human Inquiry. Sage, Thousand Oaks, CA.

Reason, P., Rowan, J. (Eds.), 1981. Human Inquiry: A Sourcebook of New Paradigm Research. Wiley, Chichester.

Ridgway, V.F., September 1956. Dysfunctional consequences of performance measurements. Administrative Science Quarterly.

Rosanas, J.M., Velilla, M., 2005. The ethics of management control systems: developing technical and moral values. Journal of Business Ethics 57 (1), 83-93.

Rowe, C., Birnberg, J.G., Shields, M.D., 2008. Effects of organizational process change on responsibility accounting and managers' revelations of private knowledge. Accounting, Organizations and Society 33 (2-3), 164-198.

Scapens, R., 2006. Understanding management accounting practice; a personal journey. British Accounting Review 38 (1), 1-30.

Scapens, R., Jazayeri, M., 2003. ERP systems and management accounting change: opportunities or impacts? A research note. European Accounting Review 12, 201-233.

Schein, E.H., 1985. Organisational Culture and Leadership. Jossey-Bass, San Francisco.

Scott, W.R., 1995. Institutions and Organisations. Sage, Thousand Oaks, CA.

Scott, W.R., 1981. Developments in organisation theory. 1960-1980. American Behavioural Scientist 24 (3), 407-422.

Seal, W., Cullen, J., Dunlop, A., Berry, T., Ahmed, M., 1999. Enacting a European supply chain: a case study on the role of management accounting. Management Accounting Research 10, 303-322.

Seal, W.J., Berry, A.J., Cullen, J., 2004. Disembedding the supply chain; Institutional reflexivity and interfirm accounting. Accounting, Organizations and Society 29 (1), 73-92.

Shank, J.K., 1996. Analysing technology investments-from NPV to strategic cost management (SCM). Management Accounting Research 7, 185-197.

Shotter, J., 1993. Conversational Realities: Constructing Life Through Language. Sage, London.

Shotter, J., 2003. Wittgenstein's philosophy and action research. Concepts and Transformations 8 (3), 295-302.

Simons, R., 1994. How new top managers use control systems as levers of control. Strategic Management Journal 15 (3), 169.

Simons, R., 1995. Levers of Control, How Managers Use Innovative Control Systems to Drive Strategic Renewal. Harvard Business School Press, Boston, MA.

Slagmulder, R., 1997. Using management control systems to achieve alignment between strategic investment decisions and strategy. Management Accounting Research 8, 103-139.

Smith, D., Murray, K., 1997. Coping Mechanisms: The Use of Informal Techniques to Deal with the Uncertainty of Investment Decisions. Chartered Institute of Management Accountants, London.

Smith, J.A., Morris, J., Ezzamel, M., 2005. Organisational change, outsourcing and the impact on management accounting. The British Accounting Review 37, 415-441.

Soin, K., Seal, W., Cullen, J., 2002. ABC and organizational change: an institutional perspective. Management Accounting Research 13, $249-271$.

Speklé, R.F., 2001. Explaining management control structure variety: a transaction cost economics perspective. Accounting. Organizations and Society 26 , 419-441.

Stringer, C., 2006. Performance management: an empirical study. Unpublished PhD Thesis, University of Otago, New Zealand.

Stringer, C., 2007. Empirical performance management research: Observations from AOS and MAR. Qualitative Research in Accounting and Management 4 (2), 92.

Thorpe, R., Holt, R., Macpherson, A., Pittaway, H., 2005. Using knowledge in small and medium sized firms; a systematic review of the evidence. International Journal of Management Reviews 7 (4), 257-282.

Tomkins, C., 2001. Interdependencies, trust and information in relationships, alliances and networks. Accounting, Organizations and Society 26, 161-191.

Tuomela, T.-S., 2005. The Interplay of different levers of control: A case study of introducing a new performance measurement system. Management Accounting Research, 293-320.

Vaivio, J., 2004. Mobilizing local knowledge with "proactive" non-financial measures. European Accounting Review 13, 39-71.

Van der Meer-Kooistra, J., Scapens, R.W., 2004. The governance of lateral relations: between and within organisations. Paper presented at the Annual Congress of the European Accounting Association, Prague.

Van der Meer-Kooistra, J., Vosselman, E.G.J., 2000. Management control of interfirm transactional relationships: the case of industrial renovation and maintenance. Accounting, Organizations and Society 25, 51-77.

Van der Meer-Kooistra, J., Vosselman, E.G.J., 2006. Research on management control of interfirm transactional relationships: whence and whither. Management Accounting Research 17, 227-237.

Van de Ven, A.H., Johnson, P.E., 2006. Knowledge for theory and practice. Academy of Management Review 31 (4), 802-821.

Weick, K., 1995. Sense Making in Organisations. Sage, Thousand Oaks, CA.

Williamson, O.E., 1973. Markets and hierarchies. Some elementary considerations. American Economic Association 63 (2).

Williamson, O.E., 1985. The Economic Institutions of Capitalism. Free Press, New York.

Williamson, O.E., 1996. The Mechanisms of Governance. Oxford University Press, New York.

Williamson, D., 2007. The COSO ERM Framework: a critique from systems theory of management control. International Journal of Risk Assessment and Management 7 (8), 1089-1119.

Woods, M., 2007. Linking Risk Management to Strategic Controls: a case study of Tesco plc. International Journal of Risk Assessment and Management 7 (8), $1074-1088$.

Zenger, T.R., 2002. Crafting internal hybrids: complementarities, common change initiatives and the team-based organization. International Journal of the Economics of Business 9, 79-95. 